\title{
Criminals or Patients? Towards a Tragic Conception of Moral and Legal Responsibility
}

\author{
Mark Coeckelbergh
}

Published online: 7 March 2010

(C) The Author(s) 2010. This article is published with open access at Springerlink.com

\begin{abstract}
There is a gap between, on the one hand, the tragic character of human action and, on the other hand, our moral and legal conceptions of responsibility that focus on individual agency and absolute guilt. Drawing on Kierkegaard's understanding of tragic action and engaging with contemporary discourse on moral luck, poetic justice, and relational responsibility, this paper argues for a reform of our legal practices based on a less 'harsh' (Kierkegaard) conception of moral and legal responsibility and directed more at empathic understanding based on the emotional and imaginative appreciation of personal narratives. This may help our societies and communities to better cope with unacceptable deeds by individuals who are neither criminals nor patients, to make room for praise as well as blame and punishment, and to set up practices and institutions that do not rely on a conception of responsibility that is hard to bear for all of us.
\end{abstract}

Keywords Responsibility · Criminal law · Tragedy · Kierkegaard · Imagination · Relations

\section{Introduction}

Some acts of violence are incomprehensible to society. Consider shootings of innocent people in schools or rapes of young children. We feel angry but also helpless: how should we understand what goes on? We usually turn to our legal system and criminal law, but this system has its own difficulties in coping with such 'hard' cases: should we consider the persons who do these things criminals or patients? Do they know what they are doing and do they need to be punished, or do we need to offer them treatment? Do we need a judge or a doctor? Shall we send the person to jail or to hospital? Failing to categorize these people, we might call them 'monsters', which is a traditional strategy in naming transgression and the incomprehensible. But this does not solve the problems of how to make sense of these

M. Coeckelbergh $(\square)$

Department of Philosophy, University of Twente, P.O. Box 217, 7500 AE Enschede, Netherlands e-mail: m.coeckelbergh@utwente.nl 
acts and how to ascribe moral and legal responsibility. Rather, it testifies to our failure to deal with them.

A common way for philosophers to discuss such problems is to engage in a discussion about free will and determinism. In this paper, I choose a different route and use the concept of tragedy. I argue that these problems should not surprise us given the gap between, on the one hand, what I call the 'tragic' nature of not only pathological but almost all human action and, on the other hand, our 'untragic' existing moral and legal frameworks with their absolute conception of guilt and their focus on individual agency. Drawing on Kierkegaard's conception of tragic action, Nussbaum's view of 'poetic justice', and relational conceptions of responsibility, I sketch the contours of an alternative conception of moral and legal responsibility that is better able to cope not only with what should never have happened, but also with 'normal' actions and with what we consider the best things one could ever do.

First I point to several problems with the standard way of thinking about moral and legal responsibility, which have to do with our focus on the individual, our post-Christian notion of absolute guilt, our Aristotelian way of thinking about the conditions of responsibility, our emphasis on the construction of causal narratives, and our tendency to aim for impartiality and retribution. Then I show how the concept of 'tragedy' can help us to develop an alternative framework. For this purpose, I position my argument vis-à-vis a tradition in the reception history of tragedy that laments a supposed loss of tragedy. Distancing myself from that perspective on the relation between tragedy and modernity, I interpret Kierkegaard's view of tragic action in Either/Or in order to sketch a view of responsibility that is better adapted to the nature of human action in general and to the 'hard' criminal cases noted above in particular, cases in which it is difficult to decide about guilt given the many factors that make the defendant's action not entirely his or her own: something that 'happens' as much as it is 'done'. Using Nussbaum's concept of 'poetic' justice, I then try to work out how to reform our practices of responsibility in accordance with the tragic nation of human action as an 'in between'. Finally, I respond to contemporary discussions of relational responsibility and contextualism (Duff, Norrie, Goodrich, and others) in order to further explore how the Kierkegaardian conception of responsibility can contribute to a better understanding of the relation between individuals and their social and political context.

\section{Human Action and Problems with the Standard View of Responsibility}

There is a problematic gap between the nature of human action and the way we usually ascribe moral responsibility. Standard moral theory makes assumptions about human action that compare it to playing pool: action is individual, we have control over what we do, we know what we do and have chosen the circumstances in which we do it, we can (in principle) foresee the consequences of our actions, and we can (re)construct causal stories about balls, forces, and intentions. These theoretical assumptions have fossilized in our legal systems, which only diverge from the pool assumptions in one respect: they spend more time on blaming and punishing than on praising. Unfortunately for society and for those who are involved in the legal system, the reality of human action and experience is very different.

First, human action is often not strictly individual at all, but most of our legal practices are occupied with judging whether individuals are guilty or not guilty. Sometimes a notion of collective responsibility is used (for example the concept of corporate responsibility or 
the responsibility of a state), but again the focus is on one 'point' of responsibility: the corporation, organization or state is considered as an individual. The many factors and actors that have contributed to the action remain out of sight. Perhaps they are taken into account when determining punishment, but not when determining 'guilt'. 'Guilt' itself is a term that refers back to the Christian tradition and in Protestantism much emphasis is put on the individual (individual sin). This did not change when the term became secularized in modern ethics, for instance in Kantian ethics. However, since many actions in today's complex world cannot be ascribed exclusively to one individual, there is no reason why we should keep the individual as the default locus of our moral and legal thinking.

Second, in line with that Christian tradition, guilt is seen as absolute. Although we often do not control and do not know what we do, responsibility is seen as an all or nothing affair: either you are guilty or you are not guilty. There are so many factors that contribute to what we do and what we have become-both natural and social factors-but we ascribe absolute moral responsibility and absolute legal guilt. ${ }^{1}$ Again, perhaps genetic, neurological, and socialization problems are taken into account, but they are used either to say that the defendant is (not) guilty — that is, absolutely (not) guilty-or to determine the punishment. They are not supposed to determine the degree of responsibility or guilt. If you did the deed (causal responsibility, compare the pool balls), you had control over what you were doing, and you knew what you were doing, you are guilty.

This way of reasoning goes back to the Aristotelian conditions of responsibility as put forward in the Nicomachean Ethics, which are very problematic since they are also stated in absolute terms. They demand that for us to be responsible we must have control and must not be ignorant. But often we are not in full control of our actions and their consequences and often we are ignorant about what exactly we are doing and about what will happen. So how could we ascribe any (absolute) responsibility on this basis?

In analytic philosophy, this is called the problem of moral luck (Nagel 1979; Williams 1981). We continue to treat individuals as objects of moral judgment and responsibility, yet what these individuals do depends on factors beyond their control (Nagel 1979, p. 59). However, this problem only arises if we see responsibility as absolute rather than gradual. Consider Zimmerman's summary of the moral luck argument:

1. A Person P is morally responsible for an event e's occurring only if e's occurring was not a matter of luck.

2. No event is such that its occurring is not a matter of luck. Therefore,

3. No event is such that $\mathrm{P}$ is morally responsible for its occurring.

(Zimmerman 1987, p. 374)

The premises are put in absolute terms: they assume that an event is either a matter of luck or a matter of full control. In the real world, however, this is often a matter of degree. Consider the four kinds of luck Nagel distinguishes: there is luck in the way things turn out, luck in the circumstances in which one finds oneself, luck in the traits one has, influenced by social-environmental factors, and luck in the way one is determined by antecedent circumstances (Nagel 1979). There is no reason why we should suppose that the actions of anyone judged in court should be regarded in a different way than the actions of other people. Many 'crimes' might have turned out differently, circumstances might have been different, one might have had a different upbringing, and so on. These factors may not

\footnotetext{
1 Note that this notion should not be confused with more technical legal terms such as absolute or strict
} liability. The notion 'absolute' is synonymous with 'complete' here and is opposed to 'gradual' or 'partial'. 
'excuse', that is, relieve one of all responsibility. But these factors should be taken into account not only when determining punishment, but also when determining moral responsibility or legal guilt. And of course, the degree to which one is constrained by these factors might differ, for instance in the case of people who are said to be mentally ill. But this supports viewing their and our responsibility as a matter of degree; it does not justify ascribing absolute guilt or declaring them absolutely morally incompetent.

A third problem is that as individuals and as societies we have an urgent need to understand why someone did his or her (often it is a 'his') atrocious deed, whereas the justice system is mainly focussed on getting the causal story right. At present, the system spends much time on finding out the facts. Increasingly, as our knowledge grows, this means getting in experts from fields such as psychology, psychiatry, neurology, and so on. But even if all contributing or relevant factors and facts became clear (which never is and never can be the case), even if the scientific aim was reached, the heuristic needs of the public would persist. It is not enough for us to know that someone is clinically diagnosed as a 'psychopath' and to hear about causal (or better: probability) links between predisposition and behaviour; we want to hear and tell narratives that give meaning to what seems to defy all meaning. For this purpose, our legal and social institutions are badly equipped.

A further and related problem is that the system is aimed at impartiality and deals with 'cases', whereas those who are stakeholders in legal matters are persons with personal lives, feelings, and stories. The system does not take people seriously enough as individual persons.

Finally, our moral and legal system are focussed on what goes wrong and on imposing blame and punishment on those who are found guilty. But this is only one possible focus and one possible outcome of a practice of responsibility ascription. One might also look for what goes right, what goes very well, is exemplary, and praise those who are involved (see below). Of course, if responsibility is indeed often shared and gradual, that praise should not be exclusively individual or put in absolute terms. But praise is and should beliterally - a legitimate part of moral life. Therefore, our legal institutions, if and in so far as they aim to converge with morality, ${ }^{2}$ should also regard this as their 'core business', perhaps alongside retribution. If retribution by the state can be justified at all (and perhaps it cannot be), praise by the state is also justified and required.

\section{Tragic Action, Tragic Responsibility: An Interpretation of Kierkegaard}

In order to further examine these problems and develop my suggestions, let me introduce the concept of tragedy and engage with Kierkegaard's view of the tragic.

When we use the term 'tragic' in daily speech we mean 'terrible' or 'catastrophic'. I will use the term in a sense that refers back to ancient Greek tragedy and its reception in the history of philosophy. There is a current of thought that understands modernity as fundamentally untragic: for Steiner it marks the 'death of tragedy' (Steiner 1961). He stands in a philosophical tradition that turned to ancient Greek tragedy as a remedy for what he might call our 'sick' untragic culture. In The Birth of Tragedy Nietzsche constructed the concept of the Dionysian (which involves passion and passivity) and in other

\footnotetext{
${ }^{2}$ I shall assume in this paper the so-called 'Separability Thesis' as interpreted by Hart: the 'simple contention that it is in no sense a necessary truth that laws reproduce or satisfy certain demands of morality, thought in fact they have often done so' (Hart 1994, pp. 181-182). I endorse this description and propose to add the normative claim: '.. and should aim to do so.' It is not a necessary truth that laws satisfy moral demands, but a moral requirement.
} 
writings he used the notion of amor fati (love of fate). And in his later work Heidegger turned to Greek mythology_-sometimes through Hölderlin's poems, sometimes directly as in 'The Question Concerning Technology' (1953) — to recover an attitude to the world which he also described (this time closer to the Christian tradition) as Gelassenheit.

I wish to distance my position from these recovery operations, since they are based on at least two false premises. First, human action and experience in modernity are often still tragic. Second, we should reject this fatalistic interpretation of the tragic: to recognise the tragic does not necessarily imply that one has to accept fate. In other words, it does not necessarily lead to passivity. Let me turn to Kierkegaard to support these claims. I will interpret Kierkegaard in order to develop a conception of tragic action that avoids passivity and allows us to recognise the tragic in contemporary moral and legal life. I will show how this can contribute to the conceptual foundations of an alternative practice of responsibility ascription.

Although Kierkegaard may also be seen as representative of the nostalgic view I attributed to Nietzsche and Heidegger, his work offers an insight into the nature of tragedy which allows us to discern tragedy in all human action-ancient and modern-and to construct an alternative notion of responsibility. In 'The Ancient Tragical Motif as Reflected in the Modern' (1843) Kierkegaard contrasts modern drama with ancient tragedy, but allows us to interpret tragic action in a non-fatalistic way. Of course, in ancient times the individual was bound to 'state, family, and destiny'; this is what Kierkegaard calls the 'fatalistic' element in Greek tragedy (Kierkegaard 1843, p. 116). But there is also an active element. In what I take to be a crucial passage for my purposes here, he argues that 'action in Greek tragedy is intermediate between activity and passivity (action and suffering)' (p. 117). I interpret this claim more broadly as being applicable to all human action. In particular, I take this to mean that we not only suffer from (and enjoy) what happens to us beyond our control; we also engage in activity and therefore contribute to what happens to us. Thus, human action and experience is always 'in between' the two poles of complete passivity and absolute activity. If we had no control or possibility for action whatsoever, we would be puppets on strings, pieces of wood drifting on the waves of fate. We would lose our humanity. There would be no struggle between what we want and what happens to us, no heroism. Without such a struggle, there would be no human suffering - there would be no humanity. The tragic would be lost. But if we were always completely in control, we would no longer be human either. We would be gods or superhumans who felt no resistance to our will. We would not suffer, but we could no longer be heroic. Our songs of suffering would be gone; there would be only the silence of pure activity. This is no longer tragic, but it is also no longer human. Thus, human action and human experience are situated 'in between' these extremes. This understanding of human action has important implications for thinking about responsibility. Kierkegaard, using the term 'guilt', puts it as follows:

just as the action in Greek tragedy is intermediate between activity and passivity (action and suffering), so is also the hero's guilt, and therein lies the tragic collision. [...] The tragedy lies between these two extremes. If the individual is entirely without guilt, then the tragic interest is nullified [...]; if, on the other hand, he is absolutely guilty, he can no longer interest us tragically. (Kierkegaard 1843, p. 117)

Thus, for Kierkegaard, in tragic action guilt is not absolute. He argues that modern tragedy misunderstands the tragic by making the hero absolutely responsible: 'one would throw this whole life upon his own shoulders, as being the result of his own acts', which 'would 
make him accountable for everything' (Kierkegaard 1843, p. 117). Instead, he says that the tragic has in it "an infinite gentleness" as opposed to the ethical which is 'strict and harsh' (Kierkegaard 1843, p. 118).

For our moral and legal practices, this has at least the following implications. If, indeed, not only action in (ancient) tragedy but all human action is 'between' activity and passivity, then it is tragic. If this is the case, moral responsibility and legal guilt should not be viewed as absolute but as gradual. Then we can and must imagine moral and legal practices that are more 'gentle' and less 'strict and harsh' on others and ourselves. If it is true, as argued above, that action is often joint action, that we do not always control or know what we do and what the consequences of our acts are, and that there is a need for understanding, personal narrative, and praise, then in many cases we should not ascribe absolute (criminal) responsibility or guilt to individuals. We should try to understand their stories and reform our social and legal institutions in such a way that more room is made for praise alongside blame.

This does not imply, of course, that individuals are relieved of all responsibility. This interpretation would revert to an absolute understanding of responsibility: you have it or you do not. Instead, the approach is gradual. For criminal law, this implies that judges would have to determine the degree of responsibility. Our current legal systems do this only inexplicitly when punishment is decided. In the alternative procedure I suggest, they would have to do this already at the point of determining legal responsibility (I propose to drop the term 'guilt' given its harsh connotations). In order to decide this, they would need not only knowledge about causal links between actions of the defendant and what has happened, and knowledge about the defendant's intentions and/or psychological or neurological condition at the time of the crime (if such knowledge can be gained at all); in addition, they would need to make more effort than they do now to take into account possible joint action, circumstances, upbringing, possible ignorance about consequences, etcetera. Only then can criminal responsibility be judged. If responsibility is basically answerability, as Duff has argued that it is in criminal law (Duff 2007), then our answer to those we have offended must not consist merely in a scientific account of physical causes and psychological states, but should include a broader story of the relation between me as an individual person and the constraints on what I felt, what I did, what others did, what I could have done under the circumstances, what others could have done, what I could have known at the time, what I have become, and so on. This requires moral imagination from the defendant, from the judge, and from other stakeholders in society to (re-)construct a story that not only identifies causal relations, but also gives meaning to what has happened and allows the ascription of gradual responsibility. In other words, we need not only an 'account' but also a story.

This conception of responsibility, then, also has important implications for judgment and for the position of the judge. Judging is no longer done from a fixed, detached, and impartial point of view but is involved, engaged, and connected to others and to the community.

\section{Understanding, Empathy, and Praise}

In order to further develop this imaginative-narrative understanding of practices of responsibility ascription, let me use Nussbaum's notion of 'poetic justice'. In many of her works she has argued that we should see moral judgment as an imaginative enterprise: it requires us to attend to the particulars of a situation and to exercise our empathy in order to know how it would be if we were in the other person's shoes, that is, if we were born in that 
other environment, grew up under those different circumstances, etc. Would we have acted differently? Nussbaum has argued that by reading novels we can develop a 'literary' imagination. Literature shows us how we and our lives are both similar to and different from (those of) others, and therefore contributes to a better understanding of those others and of those other lives. Novels train and entertain the reader's emotions and imagination, and this is precisely what we need for what Nussbaum calls 'public thinking' (Nussbaum 1995, p. 5). In Poetic Justice, Nussbaum applies this view to legal judgment. Just as the reader or the 'judicious spectator' exercises his 'power of imagining vividly what it is like to be each of the persons whose situation he imagines' (p. 73), the judge should have 'an emotional repertory' (p. 77). While this does not mean that the judge is not constrained in various ways by legal procedures, rules and other tight institutional constraints (pp. 116118 ), and while emotional-imaginative reasoning does not exhaust all the types of reasoning one needs and uses as a judge, Nussbaum calls for empathy and-going beyond empathy-for 'assessing from her own spectatorial viewpoint the meaning of those sufferings and their implications for the lives involved' (p. 90). She argues that what makes the situation of the poor or oppressed especially bad is that 'it might have been otherwise' (p. 91). We ourselves could have had their fate. This is what good novels teach us. Therefore, 'the ability to think of people's lives in the novelist's way is (...) an important part of the equipment of a judge' (p. 99). Discussing a legal example, Nussbaum shows that a good judge is 'able to enter into the existence of one who is (rightly) feared and loathed by society, seeing the interests and rights of the prisoner, and his special circumstances, without fully sharing his emotions and motives' (p. 103). This does not rule out trying to be impartial or universalising one's judgment. There is no need to become a poet. But using one's imagination as a judge allows the voices of the excluded to 'come forth from their veils and into the light' (p. 119). She concludes that unless judges are 'capable of fancy and sympathy', 'interminable generations of prisoners and slaves will dwell in pain around us and have less hope of freedom' (p. 121).

If this vision of moral 'spectatorship' is extended from judges to all stakeholders in our legal institutions - including the public and the media - then we can reasonably hope for a practice of responsibility ascription that is less 'harsh' in the way I suggested in my discussion of Kierkegaard. Although imagining the life, circumstances, and feelings of the person who is called to answer does not guarantee that our ascription of responsibility will always be entirely right, using our emotional and empathic capacities contributes to a more comprehensive investigation of that realm of action which we may call, with Kierkegaard, the 'in between', which truly is the realm of human action. As long as we are human, that is, as long as we act in between absolute activity and absolute passivity, as long and in so far as our action is tragic, there is no absolute responsibility. Therefore, if and in so far as we consider the other and indeed ourselves as human, we must be more mild in our practices of responsibility ascription. To stick to our harsh ways in these matters is dehumanizing, since it fails to recognise the true nature of much human action as having its home in the Kierkegaardian 'in between', that is, as being significantly and profoundly tragic.

Finally, as much as this alternative conception of responsibility and legal practices meets the demand for understanding those whom we call to answer for the wrongs they have done, it also makes room for praising those who have done right. In the gradual view of responsibility suggested here, such praise cannot be absolute, but it is all the more required. If it is indeed the case that human action is tragic in the way outlined above, then we have more reason, not less, to praise those who in spite of the difficult circumstances and tragic stories of human life manage to do good. Moreover, from our position as 
involved, engaged judges related to others, praise is at least as adequate as blame when it comes to developing and sustaining our social, communal life. And in the Aristotelian view that inspired Nussbaum, this would be seen as a virtue, as part of what constitutes the good, flourishing human life. I conclude that these are good reasons to transform our legal and social systems from institutions that are mainly concerned with wrongdoing (i.e., crime) into institutional platforms for empowering people to do good. Given the tragic character of much human action, people who try to do good need all the institutional and public assistance they can get. In order to make living together better, we not only need imaginative judges who can prevent the terrible, but also need to foster the emotional and imaginative capacities of all citizens, and set up or support institutions that strengthen solidarity based on the use of these capacities.

However, what if our current institutions do not promote good, but rather embody systematic injustice and violence? If they do, can we change this as individuals, however sensitive and imaginative we may be?

\section{Individuals and Contexts ${ }^{3}$}

The issue of institutional change raises questions about the relation between individuals and society. How should responsibility be distributed between individuals and society, given the influence of social context on individual action? Are good intentions and welltrained emotional and cognitive capacities enough to bring about change? Is significant institutional change possible given modern conditions? I cannot fully answer these questions within the scope of this article. But let me turn to relational views of responsibility in order to briefly explore how a Kierkegaardian conception of responsibility could contribute to understanding and evaluating the relation between individuals and their social and political context. This will also give me the opportunity to respond to some contemporary views of the relation between responsibility, community, and context.

As noted previously, Duff has claimed that responsibility must be understood as answerability (Duff 2007). In 1998 he already argued that if a trial is to be legitimate at all, the person who is to be tried must be capable of responding to the charge. ${ }^{4}$ But this responding is always responding to someone or something. Understanding the criminal trial as 'a rational process of communication in which the defendant is actively involved' (Duff 1998, p. 194), Duff wrote: 'To be responsible is to be answerable. But to be answerable is to be answerable to someone or something' (Duff 1998, p. 195). Thus, this is what Gardner calls a 'relational' view of responsibility: 'responsibility is always responsibility to someone' (Gardner 2003). We try to justify or excuse ourselves to someone.

But to whom are we answerable? According to Duff's view, the criminal trial is a 'communicative process by which individuals are made to account for their actions to their community' (Haque 2008, p. 423). For Duff that community is the liberal polity. This implies that the judge, who speaks on behalf of the community, has to ask what is owed to the community of citizens. The defendant is seen as a 'responsible citizen' (Duff 1998, p. 194). According to the relational view, the judge is related to the defendant: 'the judger

\footnotetext{
${ }^{3}$ I thank the reviewers for their comments and literature suggestions concerning this issue.

4 This means that the person must be capable of responding as part of the process of the trial, but in addition the person must be accepted by the community as being the kind of person for whom responsibility is relevant. For instance, Duff requires that the person is seen as a 'responsible citizen' (see below). I believe it is enough that the person appears to have this moral-ontological feature.
} 
and the judged are part of the same community' (Norrie 2000, p. 87). ${ }^{5}$ For Gardner, however, the audience is not a particular audience but 'at the bar, if you like, of reason itself' since what matters for him is our 'ability to explain ourselves rationally' (Gardner 2003, p. 171). And for Rorty, there is no such a thing as an 'ideal audience'; he claims that 'justification is relative to an audience', that is, a particular audience (Rorty 2001, p. 261). Thus, these different definitions of the 'to whom' by relational approaches raise the issue of the tension between individual and society, between text and context, and between the universal and the particular.

What could be said about these issues from a Kierkegaardian point of view? Based on 'The Ancient Tragical Motif as Reflected in the Modern', we can infer that Kierkegaard would agree with a relational view of responsibility. For Kierkegaard, the audience to whom we are responsible would have been the polis, the political community. However, this is not Duff's liberal community but an Aristotelian polis. In his essay Kierkegaard offers what we would now call a communitarian critique of modern society. He complains about the doubt and isolation that prevail in his age (which, in his view, makes it comic rather than tragic). Instead of taking the individual out of the network of relationships, he argues, we should understand the political in terms of a constant dialogue between the individual and the background, the community. We need the chorus to speak for the community. But in Kierkegaard this 'communitarianism' does not amount to radical contextualism or a denial of human freedom. As Jegstrup interprets Kierkegaard's view: the task of tragedy 'is to make human beings recall that they are not isolated beings (...) but beings capable of freely creating their own future, good or bad, within a given horizon that posits possibility' (Jegstrup 2006, p. 28). Thus, with regard to the relation between individuals and society, Kierkegaard sees no contradiction between freedom and destiny. Human beings rest in the family, in the state, in fate. They have a sense of belonging. However, this 'state' is not the modern state, in which-according to Kierkegaard-we remain isolated. Like Arendt (1958), he turns to ancient Greece to critique modern society and understands the political in an Aristotelian way: as political animals we reach our telos (our goal as the kind of being that we are) in the political community of citizens. With regard to responsibility, we can conclude that for Kierkegaard this is the community to which we are answerable.

Whether or not we agree with Kierkegaard's communitarian view, it is interesting that his view of the tragic is not only a tool for thinking about responsibility; it can also be used to reflect on the relation between individuals and their contexts. With regard to both issues, Kierkegaard attempts to position the human in an 'in between': we are neither absolutely independent nor absolutely determined by the social and political context in which we live. This opens up possibilities for institutional change. (And of course relational views allow us to raise issues of social justice in the first place.)

Note, finally, that by centring on the 'in between', the Kierkegaardian view of responsibility is distinct from so-called post-modern views and some constructivist views that tend to foreground context at the expense of individual freedom and responsibility. Postmodern approaches, often inspired by Nietzsche, have made interesting contributions to philosophy of law. For instance, Goodrich's work has drawn attention to the problem that law tends to reduce human behaviour to rules and leaves too little room for irrationality, change, and chance (Goodrich 1986, p. 545). He understands the application of law as a heuristic process that involves negotiation 'between the hermeneutic or interpretative

\footnotetext{
5 Note that this implies that the judge should not only be sensitive to others, as Nussbaum rightly demands, but should also be sensitive to her own position as speaker on behalf of the community.
} 
community and the audience that such a community speaks to' (p. 555). In Law in the Courts of Love he even interprets law as a response to fate (Goodrich 1996, p. 203). These insights may contribute to the further development of a relational-communitarian approach to responsibility and, more generally, to more recognition of the tragic in law. And Goodrich's criticism of legal biography as a singular causal narrative removed from time and history, leading its 'second life' or 'after-life' (Goodrich 1986, p. 559), could enhance my discussion about poetic justice. It would also be interesting to further develop the antiNietzschean twist of my Kierkegaardian argument in response to Goodrich and others. ${ }^{6}$ Moreover, postmodernists have helped us to attend to the relation between individuals and the power structures in which they are embedded. These structures can be barriers to change or vehicles for change.

However, any view that is properly relational must distance itself from postmodernism if and in so far as that tradition implies a radical contextualism that abolishes individual agency altogether. In Punishment, Responsibility, and Justice Norrie has developed a relational critique of postmodern approaches, against 'contextualizing blame' (Norrie 2000). His relational account seems to be at least compatible with the Kierkegaardian view. Norrie argues that since individual being is 'relationally located between structure and agency', a model of responsibility should reflect both aspects by understanding it as existing 'both in and beyond individual moral agents in the same moment' (Norrie 2000, p. 201). Responsibility is shared between individuals and (others in) their communities. In this way, Norrie seeks to avoid both Kantian individualism and postmodern contextualism: the view does not separate the individual from the social relations of which she is part (Norrie 2000, p. 117), but it also avoids the denial of individual agency: 'Of course, when a crime is committed, it is committed by individual agents, not by social structures, so individual agency plays its part' (Norrie 2000, p. 220). This 'third way' between individualism and contextualism is in tune with my interpretation of Kierkegaard and deserves further discussion.

For now, I conclude that from a Kierkegaardian relational point of view, the tension between individual and society cannot and should not be resolved. The tragic manifests itself in that very tension, as it does elsewhere in our efforts to cope, conceptually and practically, with our lives. We have to live in the 'in between'.

\section{Conclusion}

I started this discussion with 'hard' cases concerning 'monsters' who seem to escape all understanding and meaning and who resist categorisation either as criminals or as patients. The conceptual framework sketched in this paper does not offer a ready solution for such cases. However, it suggests that it would be misguided to entirely isolate these cases from the rest of human action. I have suggested that in order to understand and give meaning to all human action-not just these 'hard' cases-we need to understand human action as fundamentally tragic. I have argued that if this is true, we must explore its implications for our conceptions and practices of moral and legal responsibility. Following Kierkegaard on

\footnotetext{
${ }^{6}$ Such a critique of Nietzsche would have to say more on Nietzsche's view of tragedy (1872) and engage with contemporary work in this area, for instance with the recent collection Nietzsche and Law (Mootz III and Goodrich 2008). And if for some reason one wanted to remain within the Nietzschean tradition, it might be interesting to connect my interpretation of Kierkegaard's view to the late work of Foucault, in which he understands subjectivity no longer as 'being subject to' discipline and punishment but rather in terms of what he calls 'technologies of the self'.
} 
this point, we should adopt a less 'harsh' conception of moral responsibility or legal guilt. I have explored what this requires from us: as legal professionals, but also as citizens who are part of a political community and have a stake in living together, we must develop our emotional and imaginative capacities in order to enter into the existence of those who are rightly 'feared and loathed' by society. I recommended that we set up institutions that prevent 'interminable generations of prisoners' and pay more attention to those who do good in spite of, and in response to, the tragic character of human action and human life.

While there is no guarantee that these proposed improvements to our practices of responsibility ascription will prevent many crimes, this conceptual outlook is likely to assist those of us who continue their efforts to treat and understand all people involved as humans. To the extent that they have the ability to answer our responsibility demands, we had better listen to their answer. Only then can we begin the long and tedious work of meaning, judgment, and re-action. ${ }^{7}$

Luckily we are not alone. The relational conceptions of responsibility that I explored in my discussion of the tension between individuals and contexts emphasize that we are relational beings who need communal forms of living in order to flourish, and that we can only give meaning to our lives within such a relational horizon. Perhaps one of the problems of our time is indeed - to use Kierkegaard's phrase again-that we throw our whole life upon our own shoulders. If there is anything 'monstrous', it is that harsh conception of responsibility and that harsh conception of the good life that prevails in our societies. In view of this, we should not be surprised that some shoulders are not strong enough. Tragic lives might be bearable; absolute responsibility hardly is.

Open Access This article is distributed under the terms of the Creative Commons Attribution Noncommercial License which permits any noncommercial use, distribution, and reproduction in any medium, provided the original author(s) and source are credited.

\section{References}

Arendt, H. (1958). The human condition. Chicago: The University of Chicago Press.

Duff, R. A. (1998). Law, language and community: Some preconditions of criminal liability. Oxford Journal of Legal Studies, 18(2), 189-206.

Duff, R. A. (2007). Answering for crime: Responsibility and liability in the criminal law. Oxford: Hart Publishing.

Gardner, J. (2003). The mark of responsibility. Oxford Journal of Legal Studies, 23(2), 157-171.

Goodrich, P. (1986). Law and modernity. The Modern Law Review, 49(5), 545-559.

Goodrich, P. (1996). Law in the courts of love: Literature and other minor jurisprudences. London: Routledge.

Haque, A. A. (2008). Review of answering for crime. Rutgers School of Law Newark Research Papers Series, 18(5), 423-426.

Hart, H. L. A. (1994). The concept of law (2nd ed.). Oxford: Oxford University Press.

Heidegger, M. (1953). Die Frage nach der Technik. Translated as The question concerning technology. In M. Heidegger (Ed.), The question concerning technology and other essays (pp. 3-35), (W. Lovitt, Trans.). New York: Harper and Row. (1977).

\footnotetext{
7 Acceptance alone is often not enough. We need to do something after the judgment. As suggested above, a mild conception of responsibility should not be confused with passivity. Note that here I leave open what this reaction might be. Punishment is often chosen, but it is not the only option (and putting someone in jail is certainly not the only punishment option). One might also consider reconciliation in some cases, and in any case put more creativity into conceiving of alternative reactions that are more helpful to society. I will not discuss this issue further here; this paper focuses solely on the ascription of responsibility.
} 
Jegstrup, E. (2006). Kierkegaard on Abraham's tragedy: The loss of community. PhaenEx, 1(2), 21-46.

Kierkegaard, S. (1843). The ancient tragical motif as reflected in the modern. In S. Kierkegaard (Ed.), Either/or: A fragment of life (vol. 1), (D. F. Swenson \& L. M. Swenson, Trans.). Princeton: Princeton University Press. (1944).

Mootz III, F. J., \& Goodrich, P. (2008). Nietzsche and law. Aldershot, Hampshire: Ashgate.

Nagel, T. (1979). Mortal questions. New York: Cambridge University Press.

Nietzsche, F. (1872). Geburt der Tragödie aus dem Geiste der Musik. Translated as The birth of tragedy from the spirit of music (S. Whiteside, Trans.). London: Penguin Books. (1993).

Norrie, A. (2000). Punishment, responsibility, and justice: A relational critique. Oxford: Oxford University Press.

Nussbaum, M. C. (1995). Poetic justice: The literary imagination and public life. Boston: Beacon Press.

Rorty, R. (2001). Is truth a goal of inquiry? Donald Davidson versus Crispin Wright. In M. P. Lynch (Ed.), The nature of truth. Cambridge, MA: MIT Press.

Steiner, G. (1961). The death of tragedy. London: Faber and Faber.

Williams, B. (1981). Moral luck. Cambridge: Cambridge University Press.

Zimmerman, M. (1987). Luck and moral responsibility. Ethics, 97(2), 374-386. 